\title{
Identification of New Anti-Trypanosoma Cruzi Agents in Some Uru- guayan Plants by NMR-Based Metabolomic Profiling
}

Javier Varela ${ }^{1}$, Estefania Birriel ${ }^{1}$, Javier Nargoli ${ }^{1}$, Paula Faral-Tello ${ }^{2}$, Carlos Robello ${ }^{2,3}$, Aline Coqueiro ${ }^{4}$, Young Hae Choi ${ }^{4}$, Hugo Cerecetto $^{1,5^{*}}$, Mercedes González ${ }^{1 *}$

${ }^{1}$ Grupo de Química Orgánica Medicinal, Instituto de Química Biológica, Universidad de la República, Montevideo, Uruguay

${ }^{2}$ Unidad de Biología Molecular, Instituto Pasteur de Montevideo, Montevideo, Uruguay

${ }^{3}$ Departamento de Bioquímica, Facultad de Medicina, Universidad de la República, Montevideo, Uruguay

${ }^{4}$ Natural Products Laboratory, Institute of Biology, Leiden University, Netherlands

${ }^{5}$ Área de Radiofarmacia, Centro de Investigaciones Nucleares, Universidad de la República, Montevideo, Uruguay

"Corresponding authors: Hugo Cerecetto, GGrupo de Química Orgánica Medicinal, Instituto de Química Biológica, Universidad de la República, Montevideo, Uruguay. Tel: +598 25250800; E-mail: hcerecetto@cin.edu.uy

Mercedes González, GGrupo de Química Orgánica Medicinal, Instituto de Química Biológica, Universidad de la República, Montevideo, Uruguay. Tel: +598 25258618; E-mail: megonzal@fq.edu.uy

Citation: Varela J, Birriel E, Nargoli J, Faral-Tello P, Robello C, et al. (2017) Identification of New Anti-Trypanosoma Cruzi Agents in Some Uruguayan Plants by NMR-Based Metabolomic Profiling. Arch Nat Med Chem 2017: ANMC-105. DOI: 10.29011/ANMC-105.000005

Received Date: 3 June, 2017; Accepted Date: 12 June, 2017; Published Date: 19 June, 2017

\begin{abstract}
Current available drugs to treat Chagas disease, caused by Trypanosoma cruzi, are ineffective, most of them are chemical synthetic drugs, and unfortunately the market of neglected diseases is not attractive for pharmaceutical industries. To overcome these problems, the developments of drugs from plants offer new possible solutions. Wild plants from Uruguay can be used as candidate drugs for the treatment of Chagas disease. Eighty ethanol extracts from several Uruguayan medicinal plants were prepared from different parts of the plants and collected from diverse conditions of soils and seasons: Baccharis trimera, Baccharis articulata, Baccharis usterii, Hydrocotyle bonariensis, Achyrocline satureioides, Taraxacum officinalis and Plantago major. As a primary screening their anti-Trypanosoma cruzi activity against the epimastigote form of the parasite along with the unspecific cytotoxicity in mammalian cells was evaluated. Anti-amastigote activities were determined with the selected fractions obtained from the primary screening. For the identification of the active principles from the plants, nuclear magnetic resonance based metabolomics was applied. Three Baccharis species, Hydrocotyle bonariensis and Achyrocline satureioides showed significant anti-proliferative activity in epimastigotes, but only the first ones were selective to the parasites.

The most active fractions of Baccharis species inhibited the amastigotes being selective to parasite. Through the study of the relationship between changes in chemical profiles and biological activities it was possible to identify the main active principles of the extracts as aldehyde diterpenes, and the cytotoxicity was related to furane ent-clerodanes. The development of drugs from wild plants with simple growing requirements, allow us to consider the future possibility of creating standardized cultivars, in order to perform in vivo assays and clinical trials.
\end{abstract}

Keywords: Chagas disease; anti-Trypanosoma cruzi agents; NMR based metabolomic; Baccharis trimera; Baccharis articulate; Baccharis usteri.

\section{Abbreviations:}

B. articulate : Baccharis articulate

B.trimera : Baccharis trimera 


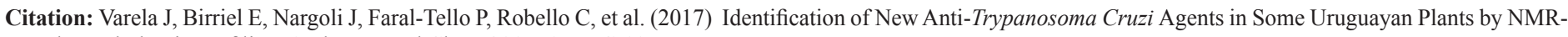
Based Metabolomic Profiling. Arch Nat Med Chem 2017: ANMC-105.

\begin{tabular}{|c|c|}
\hline B.Usteri : & Baccharis usteri \\
\hline CPRG : & Chlorophenol red- $\beta$-D-galactopyranoside \\
\hline 2D NMR & Two dimension nuclear magnetic resonance \\
\hline DMSO & Dimethylsulfoxide \\
\hline FID & Free Induction Decay \\
\hline HBMC : & Heteronuclear Multiple Bond Correlation \\
\hline HSQC : & Heteronuclear Single Quantum Coherence \\
\hline MTT & $\begin{array}{l}\text { 3-(4,5-dimethylthiazol-2-yl)-2,5- diphenyltetra- } \\
\text { zolium bromide }\end{array}$ \\
\hline NMR & Nuclear Magnetic Resonance \\
\hline PLS-DA: & Partial Least Square-Discriminant Analysis \\
\hline SI & Selectivity Index \\
\hline TLC & Thin Layer Chromatography \\
\hline TMS & Tetramethylsilane \\
\hline T. cruzi & Tryponosoma cruzi \\
\hline
\end{tabular}

\section{Introduction}

Chagas disease is caused by the flagellate protozoan Trypanosoma cruzi (T. cruzi). It is transmitted to humans through bites and concomitant defecation of different triatomine species, all of which potentially carry the parasite in their contaminated feces. Other modes of transmission include blood transfusion or blood infection from infected mother to her child, or by oral ingestion of parasite contaminated food [1]. The disease is a serious endemic illness that affects millions of people generating health, economic and social problems in the countries affected [2]. It is widespread in Central and South America, affecting 21 countries in these regions. It has been estimated that this disease affects between 5.7 million people, while 60 million remain at risk. Population mobility around the world and residence in endemic areas potentiate the possibility of expansion of the disease. A Brazilian doctor, Carlos Ribeiro Justiniano Chagas, discovered the disease in 1909, however there are still no effective chemotherapies for all its clinical forms [3]. Like other neglected diseases it is a major health problem that continues to grow as a result of inadequate therapy and the lack of an effective vaccine [4]. People suffering from neglected tropical diseases constitute an unattractive market to private sector research and for investment development [5]. Unfortunately, the current available drugs for the treatment were found to have many kinds of toxicity [6]. A fundamental problem regarding neglected tropical diseases is the lack of engagement of pharmaceutical companies in the research and development of new, not expensive and effective treatments, required for the population affected [7]. Therefore, research to uncover new solutions to treat these diseases with more effective and safer medications is of utmost importance [8]. Natural products continue to be an important source of chemotherapeutic agents, particularly those used to treat infectious diseases. Out of the 162 new chemical entities approved as antiinfective drugs by regulatory agencies over the period 1981-2002, ninety nine $(61 \%)$ were from a natural origin [9]. Natural products have a huge chemical diversity in which it is possible to find new agents for treatment of neglected tropical diseases. In this study, wild Uruguayan plants with known antibacterial and antifungal activity $[10,11]$ were tested eighty-nine against $T$. cruzi, supported by previous work of our group where plant extracts with antifungal and antibacterial properties presented significant in vitro and in vivo anti-T. cruzi activity [12]. Baccharis, trimera, Baccharis articulata, Baccharis usterii, Hydrocotyle bonariensis, Achyrocline satureioides, Taraxacum officinalis and Plantago major were the species selected to study as anti- . cruzi agents. These Uruguayan plants are able to grow in different types of soil, sandy or rocky [13]. On the other hand, the biological activity of plants might vary according to the harvest season because of secondary metabolism modifications, which result in different chemical compounds and in variable quantities.

To study the changes in the plant metabolic profiles we applied Nuclear Magnetic Resonance (NMR) spectroscopy based metabolomic. By means of NMR-based metabolomic we search for the profiling of the active principles. Nuclear magnetic resonance is traditionally considered as a prime tool in profiling, characterization, and structure elucidation of molecules, and is becoming increasingly popular for metabolomic studies [14]. Apart from its low sensitivity, NMR technique has some favorable features that give it an edge over other analytical techniques such as being non-destructive, requiring a simple sample preparation, shorter analysis time, easer quantification, and non-selectiveness towards specific metabolites. NMR has been used in the metabolic profiling of various types of samples in combination with different multivariate data analysis tools [16]. This combination has been very useful in distinguishing closely related plant species [17], as well as to identify bioactive compounds [18].

The aim of this work was to identify the potential anti- $T$. cruzi activity in plants with antifungal and antibacterial properties. We studied the relationship between the metabolic variation of plants in the different environmental conditions (type of soil and collection season) and the anti-T. cruzi activity in order to profile the active principles by NMR-based metabolomics. We also evaluated the chemical profile variation in correlation with the cytotoxic activity in order to profile the cytotoxic entities.

\section{Results}

\section{Plants collection and extraction}

Plant samples employed in this study were collected from different geographical locations of Uruguay (Figure. S1, Supplementary material) according to the following criteria of selection:

i) Weather season: the collection was done during the four seasons present in Uruguay (summer: December to March, autumn: March to June, winter: June to September, and spring: September to December).

ii) Type of soil: sandy or rocky soils. 
Citation: Varela J, Birriel E, Nargoli J, Faral-Tello P, Robello C, et al. (2017) Identification of New Anti-Trypanosoma Cruzi Agents in Some Uruguayan Plants by NMRBased Metabolomic Profiling. Arch Nat Med Chem 2017: ANMC-105.

iii) Botanic section: the whole plant, roots, leaves and flowers (in the cases of flowering time) were collected.

To obtain most of the metabolites and study the complete chemical profile, ethanol extracts were prepared from different parts of the plants, aerial parts like leaves and flowers, or roots with yields between 4 to $20 \%$ (Table 1).

\begin{tabular}{|c|c|c|}
\hline Plant & Plant section & Yielda (\%) \\
\hline Baccharis trimera & Leaves and flowers & $15-18$ \\
\hline Baccharis articulata & Leaves and flowers & $13-16$ \\
\hline Baccharis usterii & Leaves and flowers & $13-17$ \\
\hline Hydrocotyle bonariensis & Leaves & $6-11$ \\
\hline Hydrocotyle bonariensis & Stems and rhizomes & $4-7$ \\
\hline Hydrocotyle bonariensis & Flowers & $8-12$ \\
\hline Achyrocline satureioides & Leaves and flowers & $12-16$ \\
\hline Plantago major & Leaves and flowers & $5-9$ \\
\hline Plantago major & Roots & $10-15$ \\
\hline Taraxacum officinallis & Leaves and flowers & \\
\hline
\end{tabular}

${ }^{\mathrm{a}}$ The yields were informed as a range between three extraction preparations

Table 1: Yields of ethanol extracts obtained with the selected species.

\section{Biology}

The anti-proliferative capacity of eighty ethanol extracts was evaluated against the epimastigote form of $T$. cruzi, Tulahuen 2 strain. The unspecific cytotoxic activity of the extracts was assessed in a model of mammalian cells, J-774.1 murine macrophage-like cells. The selectivity to parasite is 5 expressed as the selectivity index (SI) calculated as the ratio between the $\mathrm{IC}_{50}$ against the mammalian cells and the $\mathrm{IC}_{50}$ against the parasite (Tables 2) and (Table 3). A selectivity index higher than 1.0 indicates that the extract is more toxic to the parasites than to the mammalian cells. For the ethanol extracts of the species, Taraxacum officinalis and Plantago major, no anti-epimastigote activity was observed $\left(\mathrm{IC}_{50}>100 \mu \mathrm{g} / \mathrm{mL}\right.$, Table S1, supplementary material) and the ethanol extract of Achyrocline satureioides although with certain anti-T. cruzi activity, presented high cytotoxicity to mammalian cells. Consequently, they were not included in further studies.

\begin{tabular}{|c|c|c|c|c|c|c|}
\hline Plant Species & Season (date) and soil type & Location & Plant section & $\begin{array}{c}\text { Anti T.cruzi act. } \\
\mathrm{IC}_{50}{ }^{\mathrm{a}}(\mu \mathrm{g} / \mathrm{mL})\end{array}$ & $\begin{array}{c}\text { cytotoxicity } \mathrm{IC}_{50} \text { a } \\
(\mu \mathrm{g} / \mathrm{mL})\end{array}$ & $\mathbf{S I}^{\mathbf{b}}$ \\
\hline \multirow{8}{*}{$\begin{array}{c}\text { Achyrocline sat- } \\
\text { ureioides }\end{array}$} & Summer (Feb 2012),rocky & Villa Serrana & $\begin{array}{c}\text { Leaves and flow- } \\
\text { ers }\end{array}$ & $45.0 \pm 5.1$ & $48.0 \pm 2.3$ & 1.1 \\
\hline & Summer (Feb 2012),sandy & Jauregui berry & $\begin{array}{c}\text { Leaves and flow- } \\
\text { ers }\end{array}$ & $64.7 \pm 3.6$ & $72.0 \pm 2.4$ & 1.1 \\
\hline & Summer (Feb 2012), sandy & \multirow{5}{*}{ Santa Teresa } & Leaves & $23.3 \pm 0.4$ & $11.0 \pm 1.3$ & 0.5 \\
\hline & Summer (Feb 2012), sandy & & $\begin{array}{l}\text { Stems and rhi- } \\
\text { zomes }\end{array}$ & $7.6 \pm 0.9$ & $12.0 \pm 1.2$ & 1.6 \\
\hline & Summer (Feb 2012), sandy & & Flowers & $5.2 \pm 1.6$ & $7.8 \pm 1.2$ & 1.5 \\
\hline & Summer (Feb2014), sandy & & $\begin{array}{l}\text { Stems and rhi- } \\
\text { zomes }\end{array}$ & $61.5 \pm 3.1$ & $<7.8$ & $<0.1$ \\
\hline & Summer (Feb 2014), sandy & & Flowers & $22.4 \pm 3.2$ & $<7.8$ & $<0.3$ \\
\hline & Autumn (Jun 2012),rocky/sandy & Cuchilla Alta & Leaves & $46.5 \pm 5.0$ & $37.0 \pm 1.3$ & 0.7 \\
\hline
\end{tabular}


Citation: Varela J, Birriel E, Nargoli J, Faral-Tello P, Robello C, et al. (2017) Identification of New Anti-Trypanosoma Cruzi Agents in Some Uruguayan Plants by NMRBased Metabolomic Profiling. Arch Nat Med Chem 2017: ANMC-105.

\begin{tabular}{|c|c|c|c|c|c|c|}
\hline \multirow{8}{*}{$\begin{array}{c}\text { Hydrocoty leb- } \\
\text { onariensis }\end{array}$} & Autumn (Jun 2012), lake & \multirow{3}{*}{$\begin{array}{c}\text { Facultad de } \\
\text { Ciencias }\end{array}$} & $\begin{array}{l}\text { Stems and rhi- } \\
\text { zomes }\end{array}$ & $55.0 \pm 4.2$ & $15.6 \pm 1.5$ & 0.3 \\
\hline & Winter (Aug 2013), lake & & $\begin{array}{l}\text { Stems and rhi- } \\
\text { zomes }\end{array}$ & $24.1 \pm 3.2$ & $7.8 \pm 0.9$ & 0.3 \\
\hline & Spring (Set 2012), sandy & & $\begin{array}{l}\text { Stems and rhi- } \\
\text { zomes }\end{array}$ & $56.5 \pm 3.8$ & $15.0 \pm 1.3$ & 0.3 \\
\hline & Summer (Mar2013), sandy & \multirow{3}{*}{$\begin{array}{c}\text { Barra del } \\
\text { Chuy }\end{array}$} & $\begin{array}{l}\text { Stems and rhi- } \\
\text { zomes }\end{array}$ & $44.4 \pm 2.9$ & $<7.8$ & $<0.2$ \\
\hline & Summer (Feb 2013), sandy & & Leaves & $89.6 \pm 3.3$ & $13.0 \pm 1.1$ & 0.1 \\
\hline & Summer (Feb 2013), sandy & & $\begin{array}{l}\text { Stems and rhi- } \\
\text { zomes }\end{array}$ & $36.7 \pm 2.9$ & $14.0 \pm 1.3$ & 0.4 \\
\hline & Summer (Feb 2013), sandy & \multirow[b]{2}{*}{ Punta del Este } & Flowers & $8.6 \pm 0.9$ & $7.8 \pm 0.8$ & 0.9 \\
\hline & Winter (Aug 2013), sandy & & $\begin{array}{l}\text { Stems and rhi- } \\
\text { zomes }\end{array}$ & $22.3 \pm 2.9$ & $<7.8$ & $<0.3$ \\
\hline
\end{tabular}

${ }^{a} \mathrm{IC}_{50}$ is the concentration that cause the $50 \%$ inhibition of growth; values are given in $\mu \mathrm{g} / \mathrm{mL}$ and are the mean $\pm \mathrm{S} . \mathrm{D}$. ${ }^{\mathrm{b}} \mathrm{SI}$ : Selectivity index $=\mathrm{IC}_{50}$ cytotoxicity $/ \mathrm{IC}_{50}$ T. cruzi. Reference drug: Nifurtimox, $\mathrm{IC}_{50}, T$. cruzi $=7.0 \pm 1.0, \mathrm{IC} 50, \mathrm{~J} 774-1=316.0 \pm 0.5$ values are given in $\mu \mathrm{M}$ and are the mean \pm S.D. SI $=45$

Table 2: Anti-epimastigote and cytotoxic activities of the ethanol extracts of Achyrocline satureioides and Hydrocotyle bonariensis.

\begin{tabular}{|c|c|c|c|c|c|c|}
\hline Plant species & Season (date) and soil type & Location & Plant section & $\begin{array}{c}\text { anti-T. } \\
\text { cruzi act. } \\
\text { IC } 50 \mathrm{a}(\mu \mathrm{g} / \mathrm{m})\end{array}$ & $\begin{array}{l}\text { Cytotoxicity } \\
\text { IC50a }(\mu \mathrm{g} / \mathrm{m})\end{array}$ & $\mathbf{S I}^{\mathbf{b}}$ \\
\hline \multirow{14}{*}{ Baccharis trimera } & Summer (Feb 2012), rocky & \multirow{5}{*}{ Villa Serrana } & $\begin{array}{c}\text { Leaves and flow- } \\
\text { ers }\end{array}$ & $51.5 \pm 7.6$ & $67.0 \pm 2.1$ & 1.3 \\
\hline & Autumn (Jun 2012), rocky & & $\begin{array}{l}\text { Leaves and few } \\
\text { flowers }\end{array}$ & $49.6 \pm 2.9$ & $37.0 \pm 1.4$ & 0.7 \\
\hline & Spring (Dec 2012), rocky & & Leaves & $52.0 \pm 2.7$ & $37.0 \pm 1.3$ & 0.7 \\
\hline & Winter (Aug 2013), rocky & & $\begin{array}{l}\text { Leaves and few } \\
\text { flowers }\end{array}$ & $86.5 \pm 4.9$ & $40.0 \pm 1.4$ & 0.5 \\
\hline & Summer (Feb 2014), rocky & & $\begin{array}{c}\text { Leaves and flow- } \\
\text { ers }\end{array}$ & $64.7 \pm 2.1$ & $>150$ & $>2.3$ \\
\hline & $\begin{array}{l}\text { Autumn (Jun 2012), rocky/ } \\
\text { sandy }\end{array}$ & \multirow{2}{*}{ Cuchilla Alta } & $\begin{array}{l}\text { Leaves and few } \\
\text { flowers }\end{array}$ & $43.4 \pm 2.9$ & $73.0 \pm 2.4$ & 1.7 \\
\hline & Summer (Feb 2012), sandy & & $\begin{array}{c}\text { Leaves and flow- } \\
\text { ers }\end{array}$ & $97.5 \pm 3.5$ & $38.0 \pm 1.6$ & 0.4 \\
\hline & Summer (Feb 2013), sandy & \multirow{2}{*}{ Punta del Este } & $\begin{array}{c}\text { Leaves and flow- } \\
\text { ers }\end{array}$ & $68.1 \pm 2.0$ & $75.0 \pm 2.6$ & 1.1 \\
\hline & Winter (Aug 2013), sandy & & $\begin{array}{c}\text { Leaves and flow- } \\
\text { ers }\end{array}$ & $18.3 \pm 2.4$ & $75.0 \pm 2.5$ & 4.1 \\
\hline & Summer (Feb 2012), sandy & Santa Teresa & $\begin{array}{c}\text { Leaves and flow- } \\
\text { ers }\end{array}$ & $68.9 \pm 11.7$ & $37.5 \pm 1.3$ & 0.5 \\
\hline & Spring (Oct 2013), sandy & Cabo Polonio & Leaves & $30.9 \pm 2.5$ & $>150$ & $>4.8$ \\
\hline & Summer (Feb 2013), rocky & Pozos Azules & $\begin{array}{c}\text { Leaves and flow- } \\
\text { ers }\end{array}$ & $13.6 \pm 1.2$ & $37.0 \pm 1.3$ & 2.7 \\
\hline & Summer (Mar 2013), sandy & \multirow[t]{2}{*}{ Barra del Chuy } & $\begin{array}{c}\text { Leaves and flow- } \\
\text { ers }\end{array}$ & $43.4 \pm 2.7$ & $75.0 \pm 2.2$ & 1.7 \\
\hline & Spring (Dec 2012), rocky & & Leaves & $55.2 \pm 3.9$ & $53.0 \pm 2.2$ & 0.9 \\
\hline
\end{tabular}


Citation: Varela J, Birriel E, Nargoli J, Faral-Tello P, Robello C, et al. (2017) Identification of New Anti-Trypanosoma Cruzi Agents in Some Uruguayan Plants by NMRBased Metabolomic Profiling. Arch Nat Med Chem 2017: ANMC-105.

\begin{tabular}{|c|c|c|c|c|c|c|}
\hline \multirow{4}{*}{ Baccharis usterii } & Winter (Aug 2013), rocky & \multirow{2}{*}{ Villa Serrana } & $\begin{array}{c}\text { Leaves and flow- } \\
\text { ers }\end{array}$ & $87.5 \pm 6.2$ & $50.0 \pm 2.4$ & 0.6 \\
\hline & Summer (Feb 2014), rocky & & Leaves & $78.4 \pm 3.6$ & $65.0 \pm 2.7$ & 0.8 \\
\hline & Summer (Feb 2013), rocky & \multirow{2}{*}{ Pozos Azules } & Leaves & $21.9 \pm 1.7$ & $60.0 \pm 1.8$ & 2.7 \\
\hline & Summer (Feb 2012), rocky & & Leaves & $23.0 \pm 3.0$ & $94.0 \pm 2.6$ & 4.1 \\
\hline \multirow{7}{*}{$\begin{array}{c}\text { Baccharis articu- } \\
\text { lata }\end{array}$} & Spring (Dec2012),rocky & \multirow{4}{*}{ Villa Serrana } & Leaves & $99.5 \pm 2.3$ & $35.0 \pm 1.5$ & 0.4 \\
\hline & Winter (Aug 2013), rocky & & $\begin{array}{c}\text { Leaves and flow- } \\
\text { ers }\end{array}$ & $51.9 \pm 4.2$ & $60.0 \pm 2.1$ & 1.2 \\
\hline & Winter (Aug 2013), sandy & & Leaves & $16.6 \pm 2.0$ & $100.0 \pm 2.9$ & 6 \\
\hline & Spring (Dec 2013), sandy & & $\begin{array}{c}\text { Leaves and flow- } \\
\text { ers }\end{array}$ & $33.7 \pm 2.4$ & $60.0 \pm 1.9$ & 1.8 \\
\hline & Summer (Feb 2014), rocky & Punta del Este & $\begin{array}{c}\text { Leaves and flow- } \\
\text { ers }\end{array}$ & $59.8 \pm 2.7$ & $150.0 \pm 2.7$ & 2.5 \\
\hline & Summer (Feb 2013), Sandy & Santa Teresa & Leaves & $43.6 \pm 3.2$ & $30.0 \pm 2.4$ & 0.7 \\
\hline & Summer (Feb 2012), sandy & Jauregui berry & Leaves & $22.5 \pm 4.0$ & $78.0 \pm 1.7$ & 3.5 \\
\hline
\end{tabular}

${ }^{\mathrm{a}} \mathrm{IC}_{50}$ is the concentration that cause the $50 \%$ inhibition of growth; values are given in $\mu \mathrm{g} / \mathrm{mL}$ and are the mean $\pm \mathrm{S} . \mathrm{D}$. ${ }^{\mathrm{b}} \mathrm{SI}$ : Selectivity index $=\mathrm{IC}_{50}$ cytotoxicity $/ \mathrm{IC}_{50}$ T. cruzi. Reference drug: Nifurtimox, $\mathrm{IC}_{50}, \mathrm{~T}$. cruzi=7.0 $\pm 1.0, \mathrm{IC} 50, \mathrm{~J} 774-1=316.0 \pm 0.5$ values are given in $\mu \mathrm{M}$ and are the mean \pm S.D. SI $=45$.

Table 3: Anti-epimastigote and cytotoxic activities of the ethanol extracts of Baccharis spp.

For some of the most active Baccharis spp. ethanolic extracts the anti-amastigote activities were also determined (Table 4).

\begin{tabular}{|c|c|c|c|c|c|}
\hline Plant species & $\begin{array}{c}\text { Season (date),Soil } \\
\text { type }\end{array}$ & Location & Plant section & $\begin{array}{c}\text { anti-T. } \text { cruzi act.IC }_{50}{ }^{a} \\
(\mu \mathrm{g} / \mathrm{mL}\end{array}$ & $\mathbf{S I}^{\mathbf{b}}$ \\
\hline \multirow{3}{*}{ Baccharistrimera } & $\begin{array}{l}\text { Winter (Aug } \\
\text { 2013),sandy }\end{array}$ & Punta del Este & Leaves and flowers & $18.1 \pm 1.1$ & 4.1 \\
\hline & $\begin{array}{l}\text { Spring (Oct } \\
\text { 2013),sandy }\end{array}$ & Cabo Polonio & Leaves & $27.9 \pm 2.5$ & $>5.4$ \\
\hline & $\begin{array}{c}\text { Summer (Feb2013), } \\
\text { rocky }\end{array}$ & \multirow{2}{*}{ Pozos Azules } & Leaves and flowers & $9.9 \pm 0.8$ & 3.7 \\
\hline \multirow{2}{*}{ Baccharisarticulata } & $\begin{array}{c}\text { Summer (Feb2012), } \\
\text { rocky }\end{array}$ & & Leaves & $39.0 \pm 5.3$ & 2.4 \\
\hline & $\begin{array}{c}\text { Summer (Feb2014), } \\
\text { rocky }\end{array}$ & Villa Serrana & Leaves & $22.3 \pm 1.1$ & 4.5 \\
\hline Baccharisusterii & $\begin{array}{c}\text { Summer (Feb2013), } \\
\text { rocky }\end{array}$ & Pozos Azules & Leaves & $28.1 \pm 6.9$ & 2.1 \\
\hline Reference drug & Benznidazole & & & $0.90 \pm 0.05^{\mathrm{c}}$ & - \\
\hline
\end{tabular}

${ }^{\mathrm{a}} \mathrm{IC}_{50}$ is the concentration that cause the $50 \%$ inhibition of growth; values are given in $\mu \mathrm{g} / \mathrm{mL}$ and are the mean $\pm \mathrm{S} . \mathrm{D}$. b SI: Selectivity index $=\mathrm{IC}_{50}$ cytotoxicity (Table 3) / $\mathrm{IC}_{50}$ T. cruzi (amastigotes).c $\mathrm{IC}_{50}$ is the concentration that cause the $50 \%$ inhibition of growth; values are given in $\mu \mathrm{M}$ and are the mean \pm S.D.

Table 4: Anti-amastigote and cytotoxic activities of the ethanol extracts of Baccharis spp. 
Citation: Varela J, Birriel E, Nargoli J, Faral-Tello P, Robello C, et al. (2017) Identification of New Anti-Trypanosoma Cruzi Agents in Some Uruguayan Plants by NMRBased Metabolomic Profiling. Arch Nat Med Chem 2017: ANMC-105.

\section{Metabolomic studies}

The chemical profiles of the different ethanolic extracts were determined with the ${ }^{1} \mathrm{H}$ NMR spectrum of each sample. As expected, the samples with different biological activities showed significant variations on their chemical profiles. The relationship between chemical profile variations with biological activity was evaluated by multivariate data analysis. The chemical profile is the ${ }^{1} \mathrm{H}$ NMR spectrum of ethanolic extract of each sample.

Multivariate data analysis is an essential step of any metabolomics study. These methods are used to reduce the dimensionality of multivariate dataset and thus enable to recognize possible differences or similarities among the samples. In order to identify the metabolites responsible for in vitro inhibition of $T$. cruzi growth, a supervised method, i.e. PLS-DA, was used. In this method the actual data from the bioactivity assay against epimastigotes was used as a $y$-variable. The PLS-DA analysis, 5-components explained $78.9 \%$ of the variance and Q2 value of 0.29 , was found effective in separating the high and low active samples of Baccharis species (see example for Baccharis articulata in Figure 1A. In order to identify the metabolites responsible for the cytotoxic activity of the extracts PLS-DA method was used in which the actual data from the cytotoxicity assayed against J-774.1 murine macrophage-like cells was used as the $y$-variable. A good separation was obtained between different cytotoxic activity groups, with a 2-components model that explained $55.8 \%$ of the variance and Q2 value of 0.21 (see example for Baccharis articulata in Figure 1B.

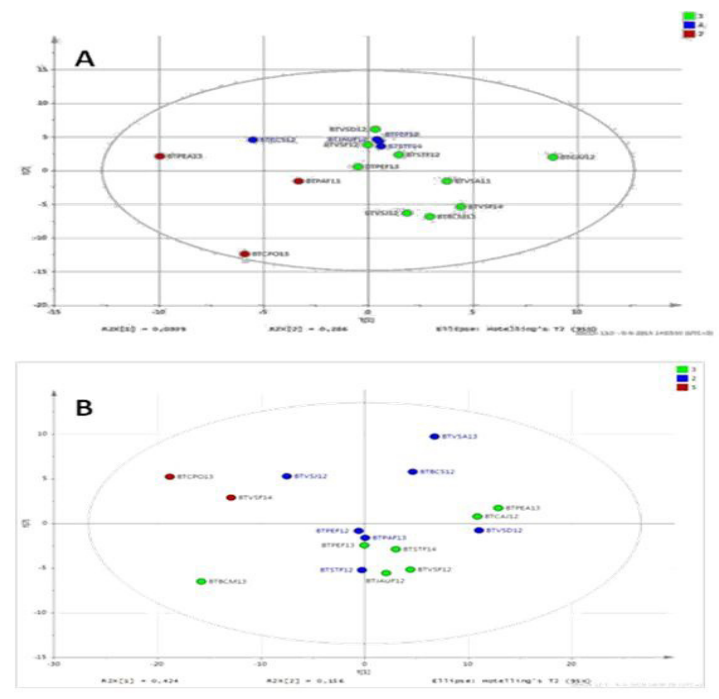

Figure:1A) Score plot of PLS-DA results obtained from all ${ }^{1} \mathrm{H}$ NMR data of Baccharis articulata samples and its anti-Trypanosoma cruzi activity showing PC1 and PC2. Blue: not interesting activity. Red: Moderate biological activity. Green: Relevant biological activity.

Figure:1B) Score plot of PLS-DA results obtained from all 1H NMR data of Baccharis articulata samples and its cytotoxic activity showing PC1 and PC2. Blue: Relevant toxicity. Red: Low toxicity. Green: Some toxicity. Yellow: No toxicity.
The PLS-DA analysis, 8-components explained $97.4 \%$ of the variance and Q2 value of 0.18, for Baccharis trimera samples using the biological activity against epimastigotes as the $y$-variable, showed that the most active group was separated from the other samples. Groups with low biological activity were not well separated by this method (Figure 2A).

To identify the metabolites responsible for the cytotoxic activity, the PLS-DA method was applied in which the actual data from the cytotoxicity assay against J-774.1 murine macrophagelike cells was used as the $y$-variable. This PLS-DA method, 9-components explained $99.2 \%$ of the variance and Q2 value of 0.18 , showed no separation between the groups of samples with different activities (Figure 2B).

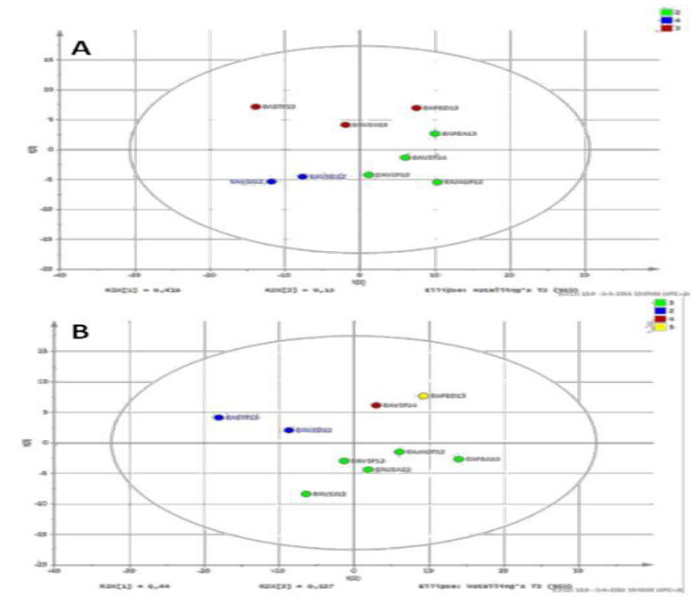

Figure 2:A) Score plot of PLS-DA results obtained from all ${ }^{1} \mathrm{H}$ NMR data of Baccharis trimera samples and its anti-Trypanosoma cruzi activity showing PC1 and PC2. Blue: not interesting activity. Green: Moderate biological activity. Red: Relevant biological activity.

Figure 2:B) Score plot of PLS-DA results obtained from all ${ }_{1} \mathrm{H}$ NMR data of Baccharis trimera samples and its cytotoxic activity showing PC1 and PC2. Blue: Relevant toxicity. Red: No toxicity. Green: Some toxicity.

For Baccharis usterii we performed a PLS-DA using the biological activity against epimastigotes of the samples as $y$-variable in order to identify the active principles. It was not possible to perform PLS-DA using cytotoxicity against J-774.1 murine macrophage-like cells like $y$-variable for two reasons.

1. Not enough number of samples required for a prediction.

2. The few samples evaluated in this study, presented the same cytotoxic activity. However, observing the biological activity changes and the constant cytotoxicity, it was possible to infer that the compounds which presented anti-T. cruzi activity and un-specific cytotoxicity were different.

\section{Discussion}

We developed a ranking to classify extracts by their ability to inhibit the growth of $T$. cruzi: when the $\mathrm{IC}_{50} \leq 10 \mu \mathrm{g} / \mathrm{mL}$ the 


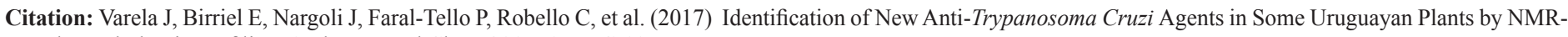
Based Metabolomic Profiling. Arch Nat Med Chem 2017: ANMC-105.

extract displayed "strong biological activity", when the $10<\mathrm{IC}_{50}$ $\leq 40$ the extract displayed "relevant biological activity", when the $40<\mathrm{IC}_{50} \leq 100$ the extract displayed "moderate biological activity", and when the $\mathrm{IC}_{50}>100 \mu \mathrm{g} / \mathrm{mL}$ the extract was "not considered" for further studies. This classification was based in previously described natural extracts with anti-parasitic activity [19]. Some Achyrocline satureioides extracts from samples collected in Villa Serrana and Jaureguiberry locations during summer of 2012 showed moderate biological activity (Table 2). The extracts of $H y$ drocotyle bonariensis showed strong to moderate anti-

T. cruzi activity. Particularly, the flowers of Hydrocotyle bonariensis, collected in summer of 2012, were the most active followed by the stems and rhizomes, collected in the same season, lacking of activity in the leaves (Table 2).

It was observed relevant antiproliferative activity of $\mathrm{Bac}$ charis genus plants (Table 3). Baccharis trimera samples showed moderate biological activity, having also in some cases relevant activity, i.e. leaves and flowers collected in Pozos Azules and Punta del Este during summer and winter of 2013 from rocky and sandy soils, respectively, and leaves collected in Cabo Polonio during spring of 2013 from sandy soil. The same was found in Baccharis articulata showing moderate biological activity and cases of relevant activity, i.e. leaves collected in Villa Serrana and Jaureguiberry during summers of 2014 and 2012 from rocky and sandy soils, respectively, and leaves and flowers collected in Punta del Este during winter of 2013 from sandy soil. Baccharis usterii samples also showed moderate biological activity with cases of relevant activity, i.e. leaves collected in Pozos Azules during summer of 2013 from a rocky soil.

The cytotoxic activity of the extracts from $A$. satureioides, $H$. bonariensis, $B$. trimera, $B$. articulata, and $B$. usterii was assessed in a model of mammalian cells, J-774.1 murine macrophage-like cells. To define the selectivity to the parasite the selectivity index (SI) was calculated as the ratio between the $\mathrm{IC}_{50}$ against the mammal cells and the $\mathrm{IC}_{50}$ against the parasite. The SI for $A$. satureioides and most of the extracts from $H$. bonariensis were less or near to 1.0 transforming these extracts into not adequate for further studies (Table 2). The B. trimera extracts presented modest cytotoxicity in several cases.

The best selectivity rates were obtained in the cases of leaves collected in Cabo Polonio during spring of 2013 from a sandy soil, and leaves and flowers collected in Punta del Este, Pozos Azules, and Villa Serrana during winter and summer of 2013 and summer of 2014 from sandy and rocky soils, respectively. B. usterii only showed good SI in leaves collected in Pozos Azules during summer of 2013 from a rocky soil. B. articulata showed, like its congener $B$. trimera, low cytotoxicity, also resulting in good SI. The best results were observed in the leaves collected in Villa Serrana and Jaureguiberry during summer of 2014 and 2012 from rocky and sandy soils, respectively. In general, the results obtained showed that the presence of flowers in plants appear to be an important factor in the decreasing of the selectivity index (Table 3).

For some of the most relevant extracts, leaves and flowers of B. trimera from Punta del Este sandy soils (winter of 2013), leaves of $B$. trimera from Cabo Polonio sandy soils (spring of 2013), leaves and flowers of $B$. trimera from Pozos Azules rocky soils (summer of 2013), leaves of B. articulate from Villa Serrana rocky soils (summers of 2012 and 2014), and leaves of B. usterii from Pozos Azules rocky soils (summer of 214 2013), the antiamastigote activities were determined (Table 4). The amastigotes are the relevant pathogenic form living intracellularly in the host in nests; consequently moderate activity of one extract reaffirms the relevance of this agent as a potential candidate for therapy. The results against amastigotes were in agreement with the findings against epimastigotes. The best selectivity indexes were from the two extracts of $B$. trimera, from Cabo Polonio and Pozos Azules, rocky and sandy soils respectively (Table 4). The best performance against the amastigotes was displayed by the extract from rocky soils $\left(\mathrm{IC}_{50}=9.9 \pm 0.8 \mu \mathrm{g} / \mathrm{mL}\right)$ and the best selectivity was evidenced in the extract from Sandy soils (SI > 5.4). The other extracts showed moderate to strong selectivity indexes (higher than 2.1).

Among the metabolites described in B. trimera are saponins, clerodane diterpenes and flavonoids such as quercetin, gencavanin, cirsimaritin, hispidulin, apigenin, luteolin, nepetin, genkwanin and rutin $[20,21]$. In $B$. articulata were described flavonoids, tannins and terpenes, being terpenoids the major compounds, including several triterpenes [22]. Two neoclerodan diterpenes, articulin acetate and articulin, have also been described [23]. Other components are crisosaponic acid, resinic acid, oleanolic acid, lupeol and the flavonoids such as santonin, absintin, luteolin, quercetin, genkwanin, acacetin, 7, 4-dimethyl-apigenin, cirsimaritin, salvigenin, jaceidin, jaceosidin and chondrillasterol. In the flowers it was found a furan diterpene, barticulidiol, and a clerodane diterpene, bachotricuneatin [24]. For B. usterii 4, 5-O-dicaffeoylquinic acid and 7-hydroxy-5,4'-dimethoxy-flavone have been described [25].

On the other hand, our experience in finding natural compounds as new agents against $T$. cruzi indicates that terpenoid compounds are responsible for the biological activity. In particular diterpenes and triterpenes $[12,26]$. But we could not rule out the synergistic action between various components of the extracts. In the PLS-DA score plot of $B$. articulata samples using the biological activity as $y$-variable (Figure 1A), three groups were clearly separated and directly related with their biological activity. The analysis showed that an aldehyde, related with diterpene ${ }^{1} \mathrm{H}$ NMR signals $(\delta=9.72,9.56,9.36,5.44-5.28,5.16,5.12,2.80$ and 2.08 ppm, Figure 3), was the most related compound with the differences in the biological activity in the samples [21,27,28]. 2D NMR studies allow us to infer the structure of the active principle from B.articulata as 7-hydroxy-ent-cleroda-3-en-16-lactone-18-al (Figure 3). 
Citation: Varela J, Birriel E, Nargoli J, Faral-Tello P, Robello C, et al. (2017) Identification of New Anti-Trypanosoma Cruzi Agents in Some Uruguayan Plants by NMRBased Metabolomic Profiling. Arch Nat Med Chem 2017: ANMC-105.

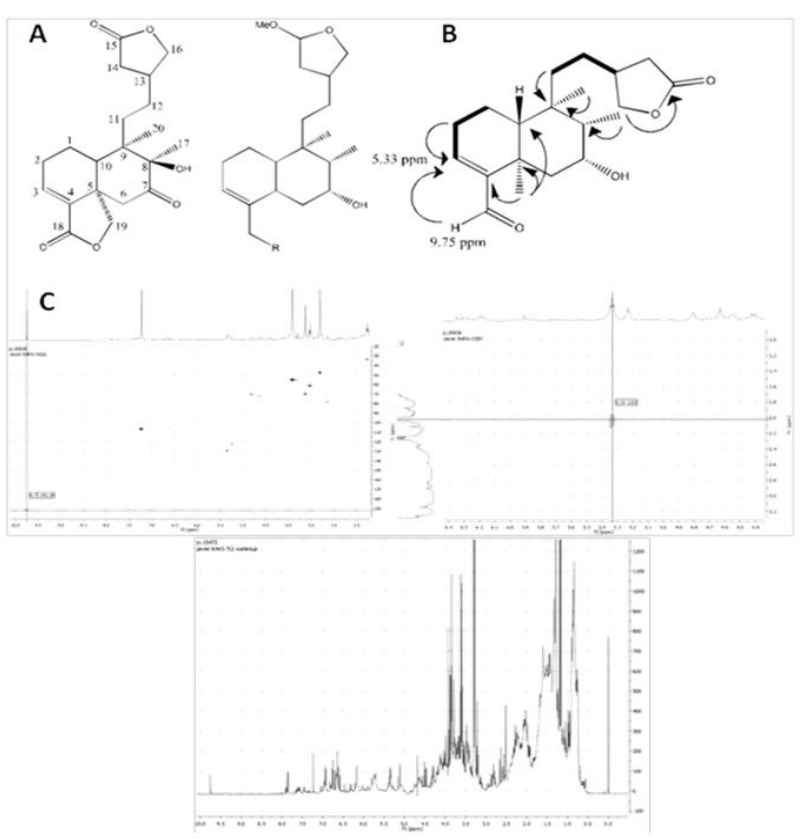

Figure: 3A) Diterpenes reported by Dai et al. (from Baccharis articulata).

Figure: 3B) Proposed structure of active principle from the identified signals in the Baccharis articulata 2D NMR related with diterpenes already reported in Baccharis species by Dai et al.

Figure: $3 \mathrm{C}$ ) $\mathrm{HMBC}$ and COSY observed correlations. Arrows denote the key HMBC correlations and bold lines indicate ${ }^{1} \mathrm{H}-{ }^{1} \mathrm{H}$ correlations.

The analysis of the PLS-DA score plot of B. articulata samples using the cytotoxic activity as y-variable (Figure 1B) suggested that the metabolites responsible for the anti-T. cruzi and cytotoxicity in $B$. articulate extracts were not the same. The relevant ${ }^{1} \mathrm{H}$ RMN signals $(\delta=6.64,5.08,3.80,3.08,2.44-2.32,1.52$ and 1.12-1.08 ppm, Figure 3) for this analysis, cytotoxic effects, were correlated with ent-clerodane furane diterpenes reported for Baccharis species [20,29]. (Figure 4).

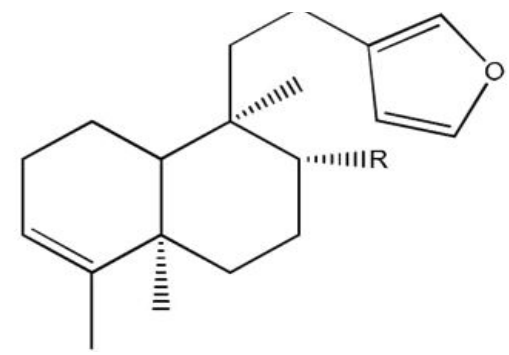

Figure 4: Furane diterpenes reported by Zdero et al. in Baccharis species.

For $B$. trimera samples the analysis of the PLS-DA using the biological activity against epimastigotes as $y$-variable (Figure 2) showed that the main ${ }^{1} \mathrm{H}$ NMR signals $(\mathrm{d}=9.60,9.40,6.36,5.68$,
$5.24,5.20,2.28,0.80$ and $0.68 \mathrm{ppm}$ ) correlated with the most active group of samples, and were similar to the ones found in $B$. articulata. It was also possible to observe signals corresponding to aldehyde-diterpenes related with compounds like those shown in (Figure 3), but we cannot affirm that was the same compound proposed for B. articulata.

In the analysis of the PLS-DA using cytotoxicity assay against J-774.1 murine macrophage-like cells as a $y$-variable (Figure $2 \mathrm{~B})$ it was possible to identify the signals $(\delta=9.44,9.28,6.36$ and $5.72 \mathrm{ppm}$ ) that 9 correlated with group 5 (no toxicity) and these signals were the same that those found for the aldehyde diterpenes. For B. usterii the PLS-DA model considering the biological activity against epimastigotes of the samples as $y$-variables was used to identify the active principles. Considering the information of the loading plot for the data of the most active sample (with the following ${ }^{1} \mathrm{H}$ NMR signals: 9.32-9.12 ppm), we suggested that the compounds with variability correlated to biological activity were also the aldehyde- diterpenes. The three Baccharis species were compared by thin layer chromatography (TLC) using Brady reagent (2,4-dinitrophenylhydrazine) to detect aldehydes, vainillinsulfuric reagent to detect terpenes, and UV light $(254 \mathrm{~nm})$ to detect UV-chromophores (Figure 5). It was observed that the three species showed compounds with aldehyde groups in their structures (positive with Brady reagent) and also these compounds were terpenes (positive with vainillin-sulfuric reagent). It was noteworthy that for $B$. trimera, the presence of at least two aldehyde diterpenes in the extract was observed. We compared the ${ }^{1} \mathrm{H}$ NMR of the three Baccharis species under study to show the similarities on the principal components of the samples (Figure 6). In the ${ }^{1} \mathrm{H}$ NMR spectrum the principal metabolites observed were diterpenes.

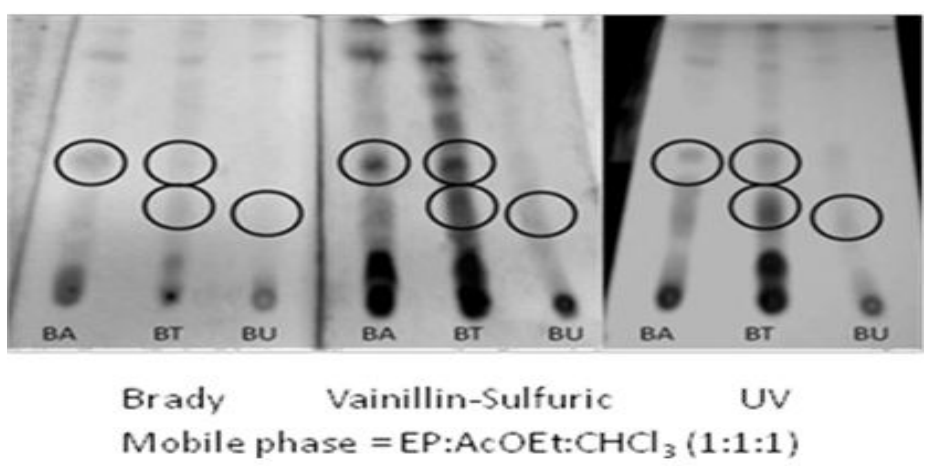

Figure 5: TLCs of Baccharis species (BA - Baccharis articulata, BT Baccharis trimera, BU - Baccharis usterii). The circles show the positive revealed zones.

\section{Materials and methods}

\section{Plant material}

The selected plants were collected considering the following variables. For seasonal variation the samples were collected through four seasons present in Uruguay (summer: December to 


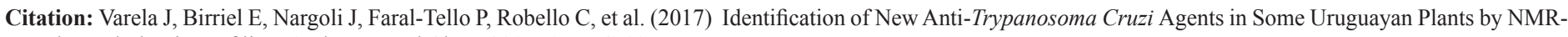
Based Metabolomic Profiling. Arch Nat Med Chem 2017: ANMC-105.

March, autumn: March to June, winter: June to September, and spring: September to December). For soil variation characteristics of land, sandy and rocky soils were considered. For all the plants employed in this study, the whole plant, roots, leaves and flowers (in the cases of flowering time) were collected.

\section{Botanical identification}

Botanical identification of the species collected was performed by Prof. Eduardo Alonso Paz (Laboratorio de Botánica, Facultad de Química-Universidad de la República, Uruguay). One specimen of each of the collected samples is preserved in the herbarium of our laboratory and in the herbarium of Facultad de Química-Universidad de la República, Montevideo, Uruguay. The registration number are: Baccharis trimera-Number 4402, Baccharis articulate - Number 4403, Baccharis Usterii-Number 4404, Hydrocotyle bonariensis -Number 4406, Taraxacum officinale-Number 4407,Plantago major -Number 4408, Achyrocline Satureioides-Number 4409.

\section{Extracts preparation}

The plant material was washed with distilled water and then oven dried at $40^{\circ} \mathrm{C}$ to constant weight. Ten grams of dried plant material was weighed and extracted with $150 \mathrm{~mL}$ of EtOH $(95 \%)$ for $48 \mathrm{~h}$ at room temperature and protected from light. After $48 \mathrm{~h}$ it was filtered and the same extraction procedure was repeated. The solvent was evaporated under reduced pressure at no more than $40^{\circ} \mathrm{C}$, to yield the ethanol extract.

\section{Anti-Trypanosoma cruzi activity}

\section{Anti-epimastigotes activity}

Trypanosoma cruzi epimastigotes (Tulahuen 2 strain) were grown at $2^{\circ} \mathrm{C}$ in an axenic milieu (BHI-Tryptose) supplemented with $5 \%$ fetal bovine serum. Cells from a 10-day-old culture (stationary phase) were inoculated into $50 \mathrm{~mL}$ of fresh culture milieu to generate an initial concentration of $1^{\prime} 10^{6}$ cells $/ \mathrm{mL}$. Cell growth was followed by measuring the absorbance of the culture at 600 $\mathrm{nm}$ every day. Before inoculation, the media was supplemented with the indicated quantity of the extracts or isolated compounds from a stock solution in DMSO, in which the final concentration never exceeded $0.4 \%$. The control was run in the presence of 0.4 $\%$ DMSO and in the absence of studied extracts. No effect on epimastigotes growth was observed due to the presence of up to $1 \%$ DMSO in the culture media. The percentage of inhibition (PGI) was calculated as follows: PGI $(\%)=\{1-[(\mathrm{Ap}-\mathrm{A} 0 \mathrm{p}) /(\mathrm{Ac}-\mathrm{A} 0 \mathrm{c})]\}$ ' 100 , where $\mathrm{Ap}=\mathrm{A}_{600}$ of the culture containing the drug at day 5; $\mathrm{A} 0 \mathrm{p}=\mathrm{A}_{600}$ of the culture containing the extract just after addition of the inocula (day 0); $A c=A_{600}$ of the culture in the absence of extract (control) at day $5 ; \mathrm{A} 0 \mathrm{c}=\mathrm{A}_{600}$ in the absence of the drug at day $0 . \mathrm{In}$ order to determine $\mathrm{IC}_{50}$ values, $50 \%$ inhibitory concentrations, parasite growth was followed in the absence (control) and presence of increasing concentrations of the corresponding extract. At day 5, the absorbance of the culture was measured and related to the control. The $\mathrm{IC}_{50}$ value was taken as the concentra- tion of extract needed to reduce the absorbance ratio to $50 \%$ and the average of three different experiments [12]. Nifurtimox, the current available used drug, was used as the positive control drug.

\section{Anti-amastigote activity}

Vero cells were plated and infected with $\beta$-galactosidase expressing trypomastigotes of the Dm28c strain [30] at a ratio of 10 parasites per cell. After $2 \mathrm{~h}$ of infection, non-internalized parasites were washed out and different concentrations of compounds ranging from $0.375 \mu \mathrm{M}$ to $25 \mu \mathrm{M}$ were added. After $72 \mathrm{~h}$ of amastigote replication, monolayers were washed and assays were developed using CPRG as substrate as previously described [31]. Color changes were quantified by measuring the absorbance at $570 \mathrm{~nm}$ using an ELx800 Universal Microplate Reader (BioTek Instruments Inc., Winooski, VT). Wells with no drug were considered as the $100 \%$ benchmark of amastigote replication and the $\mathrm{IC}_{50}$ was calculated as the $50 \%$ of replication inhibition compared with the benchmark. Benznidazole, the current available drug, was used as positive control drug.

\section{Unspecific mammalian cytotoxicity}

J-774.1 murine macrophage-like cells (ATCC, USA) were maintained by passage in Dulbecco's modified Eagle's milieu (DMEM) containing $4 \mathrm{mM} \mathrm{L}$-glutamine, and supplemented with $10 \%$ heat-inactivated fetal calf serum. J-774.1 cells were seeded $\left(1 \times 10^{5}\right.$ cells/well) in 96 well microplates with $200 \mathrm{~mL}$ of RPMI 1640 milieu supplemented with $20 \%$ heat inactivated fetal calf serum. Cells were allowed to attach for $48 \mathrm{~h}$ in a humidified $5 \%$ $\mathrm{CO}_{2} / 95 \%$ air atmosphere at $37{ }^{\circ} \mathrm{C}$ and, then, exposed to extracts for $48 \mathrm{~h}$. Afterwards, cell viability was assessed by measuring the mitochondrial-dependent reduction of MTT to formazan. For this purpose, MTT was added to cells to a final concentration of 0.4 $\mathrm{mg} / \mathrm{mL}$ and cells were incubated at $37{ }^{\circ} \mathrm{C}$ for $3 \mathrm{~h}$. After removing the media, formazan crystals were dissolved in DMSO $(180 \mathrm{~mL})$, and the absorbance at $595 \mathrm{~nm}$ was read using a microplate spectrophotometer. Results were expressed as $\mathrm{IC}_{50}$ (extract concentration that reduce $50 \%$ control absorbance at $595 \mathrm{~nm}$ ). Every $\mathrm{IC}_{50}$ was the average of five different experiments [12].

\section{Nuclear Magnetic Resonance}

Nuclear Magnetic Resonance spectroscopy was performed using the parameters explained by Kim et al. [32]. Ten mg of each extract were dissolved in $0.6 \mathrm{~mL}$ of $\mathrm{CD}_{3} \mathrm{OD}+0.15 \mathrm{~mL}$ of $\mathrm{CD}_{3} \mathrm{OD}$ with $0.05 \%$ of TMS. One dimension ${ }^{1} \mathrm{H}$ NMR spectra, ${ }^{1} \mathrm{H}-{ }^{1} \mathrm{H}$ homonuclear and inverse detected ${ }^{1} \mathrm{H}-{ }^{13} \mathrm{C}$ correlation experiments were recorded on Bruker DPX-400 spectrometer at $22.16{ }^{\circ} \mathrm{C}$ operating at a proton NMR frequency of $400.13 \mathrm{MHz}$. Methanol- $d_{4}$ was used as the internal lock. Each ${ }^{1} \mathrm{H}$ NMR spectrum consisted of 64 scans requiring $10 \mathrm{~min}$ and $26 \mathrm{~s}$ acquisition time with the following parameters: $0.16 \mathrm{~Hz} /$ point, pulse width $(\mathrm{PW})=30^{\circ}(11.3 \mathrm{~ms})$, and relaxation delay $(\mathrm{RD})=1.5 \mathrm{~ms}$. A pre-saturation sequence was used to suppress the residual $\mathrm{H}_{2} \mathrm{O}$ signal with low power selective irradiation at the $\mathrm{H}_{2} \mathrm{O}$ frequency during the recycle delay. FIDs were Fourier transformed with $\mathrm{LB}=0.3 \mathrm{~Hz}$. The resulting spectra 
Citation: Varela J, Birriel E, Nargoli J, Faral-Tello P, Robello C, et al. (2017) Identification of New Anti-Trypanosoma Cruzi Agents in Some Uruguayan Plants by NMRBased Metabolomic Profiling. Arch Nat Med Chem 2017: ANMC-105.

were manually phased and baseline corrected, and referenced to internal standard TMS at $0.0 \mathrm{ppm}$, using Mestre Nova software version 6.0

\section{Data analysis and statistics}

The ${ }^{1} \mathrm{H}$ NMR spectra were automatically reduced to ASCII files. Spectral intensities were scaled to internal standard and reduced to integrated regions of equal width (0.04) corresponding to the region of $\delta 0.0-10.0$ by AMIX software. The regions of $\delta$ 4.85-4.95 ppm and $\delta 3.2-3.4 \mathrm{ppm}$ were excluded from the analysis because of the residual signal of $\mathrm{H}_{2} \mathrm{O}$ and $\mathrm{CH}_{3} \mathrm{OH}$, respectively. Partial Least Square-Discriminant Analysis (PLS-DA) was performed with the SIMCA-P + software (v.12.0, Umetrics, Umea, Sweden).

\section{Conclusions}

Relevant biological activities against epimastigotes and amastigotes of T.cruzi were found for Baccharis genus spp. Collected in different Uruguayan locations and seasons. Also, all of them presented good selectivity against the parasite. The active principles, aldehyde-diterpenes, were identified by ${ }^{1} \mathrm{H}$ NMR-based metabolomics using the information obtained in the biological assays. The obtained results positioned B. trimera, B. articulata and $B$. usterii as candidates for new treatments of Chagas disease. Further complete characterization of the active principles and in vivo studies are currently being performed. Additionally from a phytomedicinal point of view we can infer that these extracts open a new vision in the development of safe and low cost drugs to treat Chagas disease.

\section{Conflict of interest}

The authors declare no conflict of interest.

\section{Acknowledgements}

The authors thank Eduardo Alonso Paz for his collaboration in the Botanical Classification of the plants used in this work. JV thanks ANII and CAP-UdelaR for his fellowships. This work was supported by project CSIC-UdelaR No612. Dr. A. Coqueiro thanks Ciências sem fronteiras, CAPES Foundation, Ministry of Education of Brazil, for the scholarship.

\section{References}

1. Maya JD, Orellana M, Ferreira J, Kemmerling U, López-Muñoz R, et al. (2010) Chagas disease: Present status of pathogenic mechanisms and chemotherapy. Biol Res 43: 323-331.

2. WHO (2015) Chagas disease in Latin America: an epidemiological update based on 2010 estimates. In Weekly Epidemiological Record. World Health Organization Geneva.90: 33-44.

3. Barrett MP, Croft SL (2012) Management of trypanosomiasis and leishmaniasis. Br Med Bull. 104: 175-196.
4. Tekiel V, Alba-Soto CD, González Cappa SM, Postan M, Sánchez DO (2009) Identification of vaccines candidates against Trypanosoma cruzi by immunization with sequential fractions of an epimastigote-subtracted trypomastigote cDNA expression library. Vaccine 27: 1323-1332.

5. Fevre EM, Wissmann BV, Welburn SC, Lutumba $P$ (2008) The burden of human African trypanosomiasis. PLoS Negl Trop Dis 2: e333.

6. Cabrera M, Lavaggi ML, Hernández $P$, Merlino A, Gerpe A, et al. (2009) Cytotoxic, mutagenic and genotoxic effects of new anti-T.cruzi 5-phenylethenylbenzofuroxans. Contribution of phase I metabolites on the mutagenicity induction. Toxicol. Lett 190: 140-149.

7. Dimitri N (2012) R\&D investments for neglected diseases can be sensitive to the economic goal of pharmaceutical companies. Drug Discov Today 17: 818-823.

8. Cerecetto H, González M (2010) Synthetic medicinal chemistry in Chagas' disease: Compounds at the final stage of "hit-to-lead" phase. Pharmaceuticals 3: 810-838.

9. Newman DJ, Cragg GM, Snader KM (2003) Natural products as sources of new drugs over the period 1981-2002. J Nat Prod 66: 1022-1037.

10. empone AG, Sartorelli P, Teixeira D, Prado F, Calixto I, et al. (2008) Brazilian flora extracts as source of novel antileishmanial and antifungal compounds. Mem Inst Oswaldo Cruz 103: 443-449.

11. Vivot-Lupi E, Sánchez Brizuela C, Cacik Jeifetz F, Sequin Acosta C (2009) Screening of antifungal activity of extracts present in Entre Ríos flora species. Rev Cubana Farm 43: 74-84.

12. Varela J, Lavaggi ML, Cabrera M, Rodríguez A, Miño P, et al. (2012) Bioactive-guided identification of labdane diterpenoids from aerial parts of Aristeguietia glutinosa Lam. as anti-Trypanosoma cruzi agents. Nat Prod Commun 7: 1139-1142.

13. Lahitte H, Hurrell J, Belgrano M, Jankowski L, Haloua P, et al. (1998) Biota Rioplatense II, Plantas Medicinales Rioplatenses. Ed. Literature of Latin America 41: 139 - 140.

14. Zulak KG, Weljie AM, Vogel HJ, Facchini PJ. (2008) Quantitative ${ }^{1} \mathrm{H}$ NMR metabolomics reveals extensive metabolic reprogramming of primary and secondary metabolism in elicitor-treated opium poppy cell cultures. BMC Plant Biol 8: 5.

15. Dixon RA, Gang DR, Charlton AJ, Fiehn O, Kuiper HA, et al. (2006) Applications of metabolomics in agriculture. J Agric Food Chem 54: 8984-8994.

16. Choi HK, Choi $\mathrm{YH}$, Verberne M, Lefeber AWM, Erkelens $\mathrm{C}$, et al (2004) Metabolic fingerprinting of wild type and transgenic tobacco plants by ${ }^{1} \mathrm{H}$ NMR and multivariate analysis technique. Phytochem 65 : 857-864.

17. Choi YH, Sertic S, Kim HK, Wilson EG, Michopoulos F, et al. (2005) Classification of llex species based on metabolomic fingerprinting using nuclear magnetic resonance and multivariate data analysis. J Agric Food Chem 53: 1237-1245.

18. Kim HK, Choi YH, Verpoorte R (2011) NMR-based plant metabolomics: where do we stand, where do we go? Trends Biotechnol 29 : 267-275.

19. Molina Z, Bazaldúa A, Quintanilla R, Galavitz L. (2014) Anti-Trypanosoma cruzi activity of 10 medicinal plants used in northeast Mexico. Acta Trop 136: 8-14. 
Citation: Varela J, Birriel E, Nargoli J, Faral-Tello P, Robello C, et al. (2017) Identification of New Anti-Trypanosoma Cruzi Agents in Some Uruguayan Plants by NMRBased Metabolomic Profiling. Arch Nat Med Chem 2017: ANMC-105.

20. Herz W, Pillotti AM, Soderholm AC, Shuhama IK, Vichnewski W. (1977) New ent-clerodane-type diterpenoids from Baccharis trimera. J Org Chem 42: 3913-3917.

21. Torres L, Gamberini M, Roque N, Landman M, Souccar C, et al. (2000) Diterpene from Baccharis trimera with a relaxant effect on rat vascular smooth muscle. Phytochem 55: 617-619.

22. Soicke H, Leng-Peschlow Es (1987) Characterization of flavonoids from Baccharis trimera and their antihepatotoxic properties. Planta Medica. 53: 37-39.

23. Simoes C, Auler Mentz L, Schenkel E, Irgang B, Stehmann J (1986) Popular medicine plants in Rio Grande do Sul. Porto Alegre: UFRGS186.

24. Gianello J, Giordano O (1982) Barticulidiol, um nuevo furano diterpeno aislado de Baccharis articulata Lam. (Persoon). Rev Latinoam Quím 13: $76-78$.

25. Quintana de Oliveira S, Demarchi V, Silva V, Leoneti C, Sonnet P, et al. (2014) Antioxidant properties of phenolic compounds from Baccharis articulata and B. usterii. Nat Prod Comm 9: 941-942.

26. Varela J, Serna E, Torres S, Yaluff G, Vera de Bilbao N, et al. (2014) In vivo anti-Trypanosoma cruzi activity of hydro-ethanolic extract and isolated active principles from Aristeguietia glutinosa and mechanism of action studies. Molecules 19: 8488-8502.
27. Dai J, Suttisri R, Bordas E, Soejarto D, Kinghorn A (1993) Clerodane diterpenoids from Baccharis articulata. Phytochem. 34: 1087-1090.

28. Francesca C, Castillo M. (1990) Diterpenoids from Chilean Baccharis species. Phytochem. 29: 324-325.

29. Zdero C, Bohlmann F, Solomon J, King R, Robinson H. (1989) Entclerodanes and other constituents from bolivian Baccharis species. Phytochem 28: 531-542.

30. Faral-Tello P, Liang M, Mahler G, Wipf P, Robello C (2014) Imidazolium compounds are active against all stages of Trypanosoma cruzi. Int J Antimicrob Agent 43: 262-268.

31. Buckner FS, Verlinde C, La Flamme A, Van Voorhis W (1996) Efficient technique for screening drugs for activity against Trypanosoma cruzi using parasites expressing-galactosidase. Antimicrob Agents Chemother. 40: 2592-2597.

32. Kim HK, Choi YH, Verpoorte R (2010) NMR-based metabolomic analysis of plants. Nat Protoc 5: 536-549. 